\title{
UPAYA PENINGKATAN HASIL BELAJAR BIOLOGI MELALUI PENGGUNAAN MEDIA ANIMASI PADA POKOK BAHASAN SISTEM KOORDINASI UNTUK SISWA KELAS XI SMAN 2 SIMPANG HILIR
}

\author{
Hellen Puspaningrum ${ }^{1}$ \\ Guru Biologi SMA Negeri 2 Simpang Hilir \\ Email:hellenpuspaningrum@gmail.com
}

\begin{abstract}
Abstrak: Penelitian ini bertujuan untuk memperbaiki proses pelaksanaan pembelajaran dan meningkatkan hasil belajar siswa dengan mengkombinasikan model pembelajaran kooperatif dan media animasi pada pokok bahasan sistem koordinasi pada siswa kelas XI. Bentuk penelitian yang digunakan adalah Penelitian Tindakan Kelas, dilaksanakan di kelas XI IPA SMAN 2 Simpang Hilir Tahun Ajaran 2014/2015 dengan jumlah siswa sebanyak 19 orang. Instrument yang digunakan dalam penelitian ini adalah berupa lembar observasi untuk melihat pelaksanaan pembelajaran dan soal tes pilihan ganda berjumlah 15 butir untuk mengukur hasil belajar. Hasil penelitian menunjukkan persentase pelaksanaan pembelajaran pada siklus I dan siklus II sama yaitu sebesar $100 \%$. Sedangkan hasil belajar diperoleh rata-rata sebesar 65,61 pada siklus I dan meningkat menjadi 80,00 pada siklus II. Dengan demikian dapat disimpulkan bahwa penerapan pembelajaran kooperatif disertai media animasi dapat meningkatkan hasil belajar siswa.

Kata Kunci: pembelajaran kooperatif, media animasi, hasil belajar
\end{abstract}

Abstract: The aim of this research was to improve the process of learning and students learning outcome by combining cooperative learning and animationmedia on coordination systemsubject. This study conducted through a Classroom Action Research. This research was done in the class XI IPA SMAN 2 Simpang Hilir in Academic Year 2014/2015. They consisted of 19 students. The instruments was used in this research was an observation sheet and multiple choice questions that consisted 15 questions. It revealed that was $100 \%$ on first cycle and second cycle. The students averages on first cycle were 65.61, and on second cycle were 80.00 . Based on the mentioned results above, it can be

${ }^{1}$ Hellen Puspaningrum adalah Guru Biologi SMA Negeri 2 Simpang Hilir 
concluded that improving students achievement through cooperative learning and animation media on coordination system subject of class XI IPA SMAN 2 Simpang Hilir was successful to be implemented.

Keywords: copperative learning, animation, learning outcome

Perkembangan ilmu pengetahuan dan teknologi telah membawa perubahan di hampir semua aspek kehidupan manusia, yang membawa kita ke dalam era persaingan global yang semakin ketat. Agar mampu berperan dalam persaingan global, maka sebagai bangsa kita perlu terus mengembangkan dan meningkatkan kualitas sumber daya manusianya. Oleh karena itu, peningkatan kualitas sumber daya manusia merupakan kenyataan yang harus dilakukan secara terencana, terarah, intensif, efektif dan efisien dalam proses pembangunan.

Pendidikan pada dasarnya berlangsung dalam bentuk belajar mengajar yang melibatkan dua pihak yaitu guru dan siswa dengan tujuan yang sama dalam rangka meningkatkan hasil belajar siswa. Dalam keseluruhan proses pendidikan di sekolah, kegiatan belajar mengajar merupakan kegiatan yang paling pokok. Hal ini berarti berhasil tidaknya pencapaian tujuan pendidikan banyak bergantung pada bagaimana proses belajar mengajar yang dialami oleh siswa sebagai peserta didik yang dalam hal ini menjadi tanggung jawab guru sebagai pendidik. Guru memiliki berbagai peran dan fungsi dalam proses pembelajaran. Guru sebagai fasilitator memberikan kemudahan kepada siswa dalam menanamkan konsep yang menjadi tuntutan kurikulum. Sebagai dinamisator guru perlu menciptakan situasi dan kondisi hidup dan tidak monoton supaya semangat belajar siswa dapat meningkat. Sebagai mediator guru perlu bertindak sebagai media terhadap siswa dalam mengembangkan pengetahuan yang dimilikinya. Sebagai evaluator, guru perlu menilai kemajuan siswa supaya mereka dapat melakukan perbaikan-perbaikan supaya hasil belajarnya dapat meningkat. Sebagai instuktur, guru perlu memberikan perintah yang baik dan tepat dalam bentuk tugas-tugas kepada siswa supaya mereka lebih aktif belajar. Sebagai manajer, guru perlu memiliki jiwa kepemimpinan yang tinggi sehingga nampak berwibawa di mata siswa (Sanjaya, 2008).

Guru sebagai seorang pendidik dan sebagai orang yang memberi ilmu pengetahuan kepada anak didik harus betul-betul memahami kebijakankebijakan pendidikan. Dengan pemahaman itu guru memiliki landasanlandasan berpijak dalam melaksanakan tugas di bidang pendidikan. Namun, perlu dipahami bahwa guru memang bukanlah satu-satunya sumber belajar, walaupun tugas, peranan, dan fungsinya dalam proses belajar mengajar sangat 
penting. Prestasi yang dicapai anak didik tidak hanya dipengaruhi oleh tingkat pengetahuan guru terhadap materi pelajaran yang akan diajarkan, tetapi yang juga ikut menentukan adalah model mengajar dan media pembelajaran yang digunakan.

Upaya yang telah dilakukan untuk meningkatkan hasil belajar pada mata pelajaran Biologi belum mencapai hasil yang maksimal, hal ini dibuktikan dengan masih rendahnya perolehan nilai siswa pada ujian akhir nasional. Berdasarkan data yang diperoleh dari SMA Negeri 2 Simpang Hilir, nilai ratarata Ujian Nasional Biologi pada tahun ajaran 2011/2012 adalah 8.27; tahun 2012/2013 rata-ratanya 7.09; dan terakhir tahun ajaran 2013/2014 semakin menurun dengan nilai rata-rata 4.09. Masih rendahnya hasil belajar tersebut disebabkan berbagai faktor yang terlibat langsung dalam proses pembelajaran diantaranya faktor guru, siswa, metode mengajar, media pembelajaran, sarana dan prasarana pendidikan yang digunakan maupun materi pelajaran.

Pembelajaran biologi diharapkan dapat menjadi wahana bagi peserta didik untuk mempelajari diri sendiri dan alam sekitar, serta menerapkannya dalam kehidupan sehari-hari.Dalam tubuh manusia sendiri banyak sistemsistem kerja yang saling berhubungan sehingga menopang keberlangsungan hidup manusia.Dalam proses pembelajaran kadang-kadang siswa tidak mengerti apa yang dijelaskan oleh guru dan ingin lebih mengetahui apa yang sebenarnya terjadi dalam tubuhnya. Misalnya bagaimana proses gerak refleks terjadi? Bagaimana cara kerja sistem saraf pada manusia? Atau bagaimana pengaruh obat-obatan terhadap tubuh?, mereka tidak pernah melihatnya. Sehingga dibutuhkan media pembelajaran untuk menjelaskan apa yang sebenarnya terjadi, dan menarik perhatian siswa untuk belajar. Pemilihan media disesuaikan dengan tingkat perkembangan anak dan konsep yang akan diajarkan agar siswa lebih mudah memahami pelajaran yang diajarkan dan tidak menimbulkan kebosanan.

Keadaan kelas XI IPA di SMAN 2 Simpang Hilir yang umumnya selalu diajar dengan model pembelajaran langsung khususnya metode ceramah menunjukkan bahwa siswa kurang bersemangat dalam menerima pelajaran dan menimbulkan kejenuhan siswa. Ketika belajar di dalam kelas, siswa mengetahui apa yang dijelaskan oleh guru namun apabila keluar dari proses belajar mengajar, kurang sekali pengetahuan yang diberikan oleh guru yang membekas di benak mereka. Disamping hal tersebut, gangguan dalam kelas ketika pembelajaran berlangsung besar, perhatian siswa juga rendah karena dalam proses belajar-mengajar siswa terkadang mengantuk, disamping dipaksa menerima materi dari penjelasan guru juga disebabkan karena pelajaran biologi berada di akhir jam pelajaran. Hal-hal tersebut di ataslah yang menyebabkan 
bila diberikan tes hasil belajar oleh guru, hasilnya rendah.Dari ulangan umum yang dilakukan pada semester I tahun ajaran 2014/2015, sebanyak 34,29\% dari 19 siswa yang memperoleh nilai ketuntasan belajar di atas nilai standar 67 .

Berdasarkan kenyataan tersebut di atas, maka perlu dilakukan perbaikan dalam kegiatan pembelajaran agar nilai siswa meningkat. Masalah-masalah dalam proses pembelajaran seperti kejenuhan dan kurangnya semangat siswa, gangguan dalam kelas, serta perhatian siswa yang rendah karena mengantuk perlu segera diatasi. Untuk masalah pelajaran biologi berada di akhir jam pelajaran yang kebanyakan siswa merasa mengantuk, tidak mungkin memindahkan jam pelajaran biologi ke jam pelajaran lain karena akan mengganggu jadwal pelajaran lain. Oleh karena itu harus diberikan solusi terhadap masalah-masalah di atas.Salah satu solusi pemecahannya adalah dengan penggunaan media dalam pembelajaran.Media yang digunakan dapat menarik siswa untuk semangat belajar. Media banyak macamnya, salah satunya adalah media animasi, yang merupakan salah satu contoh pemanfaatan teknologi dalam menunjang proses pendidikan. Media ini dapat meningkatkan semangat dan perhatian siswa untuk belajar, sehingga gangguan dalam kelas dapat diminimalisir, demikian juga bagi siswa yang mengantuk, akan membuat mereka tergerak untuk memperhatikan pelajaran. Serta penggunaan animasi ini dapat menanamkan konsep dan pemaknaan yang sama dalam otak siswa dibandingkan dengan media lain seperti gambar.

Menurut Utami (2007), animasi menjadi pilihan untuk menunjang proses belajar yang menyenangkan dan menarik bagi siswa dan juga memperkuat motivasi, dan juga untuk menanamkan pemahaman pada siswa tentang materi yang diajarkan. Animasi yang pada dasarnya adalah rangkaian gambar yang membentuk sebuah gerakan memiliki keunggulan dibanding media lain seperti gambar statis atau teks. Animasi untuk menarik perhatian siswa dan memperkuat motivasi, biasanya berupa tulisan atau gambar yang bergerakgerak, animasi yang lucu, aneh yang sekiranya akan menarik perhatian siswa. Keunggulan animasi dalam hal ini gambar yang bergerak adalah kemampuannya untuk menjelaskan suatu kejadian secara sistematis dalam tiap waktu perubahan.Hal ini sangat membantu dalam menjelaskan prosedur dan urutan kejadian. Animasi gambar dibuat dengan bantuan program macromedia flash, tetapi dalam penelitian ini penulis mengambilnya dari internet. 
Sedangkan animasi yang berupa kata atau tulisan yang bergerak dapat dibuat dengan bantuan microsoft power point.

\section{METODE PENELITIAN}

Bentuk penelitian yang digunakan pada penelitian ini adalah penelitian tindakan kelas (Classroom ActionResearch) melalui penerapan pembelajaran kooperatif disertai media animasi. Penelitian dilakukan di kelas XI IPA SMAN 2 Simpang Hilir semester II Tahun Pelajaran 2014/2015 dengan siswa berjumlah 19 orang yang terdiri dari 8 siswa laki-laki, 11 siswa perempuan. Penelitian ini dilaksanakan dalam 2 siklus, Siklus I dilaksanakan tanggal 14 Mei 2015, siklus II dilaksanakan tanggal 16 Mei 2015, dan dalam pelaksanaan dibantu oleh 2 orang observer yaitu satu orang guru Fisika SMAN 2 Simpang Hilir dan satu orang guru Biologi SMAN 3 Simpang Hilir. Adapun persiapan yang dilakukan sebelum melaksanakan penelitian adalah: Menyusun perangkat pembelajaran yang digunakan dalam pelaksanaan pembelajaran, meliputi: (1) silabus, yang digunakan sebagai acuan materi. (2) RPP. (3) Bahan ajar dan media berupa buku Biologi dan Video animasi. (4) LKS. Menyusun instrument penelitian berupa: (1) soal tes, untuk mengetahui ketuntasan hasil belajar siswa. (2) lembar observasi, diberikan kepada dua orang observer untuk mengamati proses pembelajarn yang dilaksanakan peneliti di kelas. Instrument divalidasi oleh dua orang rekan sejawat. Melakukan uji coba soal tes untuk mengetahui apakah soal tes mempunyai reliabilitas yang memadai untuk digunakan dalam penelitian dengan rumus K-R 20 (Kuder Richardson) sebagai berikut :

$$
r_{11}=\left(\frac{\mathrm{k}}{\mathrm{k}-1}\right)\left(\frac{\mathrm{V}_{\mathrm{t}}-\sum p q}{\mathrm{~V}_{\mathrm{t}}}\right) \text { Arikunto, (2010) }
$$

Pelaksanaan penelitian tindakan kelas ini dirancang dalam 2 siklus.Setiap siklus terdiri dari 1 pertemuan, dalam setiap pertemuan dilaksanakan 4 tahapan kegiatan pokok yang harus dilakukan. Menurut Arikunto (2010) "secara garis besar terdapat 4 tahap yang lazim dilalui, yaitu perencanaan, pelaksanaan, pengamatan dan refleksi”. Adapun tahap penelitian ini yaitu siklus I tahapannya adalah perencanaan tindakan I, pelaksanaan tindakan I, pengamatan tindakan I, dan refleksi. Untuk siklus II yaitu, 
perencanaan tindakan II, pelaksanaan tindakan II, pengamatan tindakan II, dan refleksi.

Proses pelaksanaan pembelajaran dikatakan berhasil apabila $80 \%$ pada siklus I dan $90 \%$ pada siklus II siswa di kelas dapat mencapai KKM dari lembar observasi proses pelaksanaan pembelajaran yang terlaksana.Siswa dikatakan berhasil atau tuntas dalam belajar apabila hasil belajar siswa memenuhi kriteria ketuntasan minimal (KKM) yang telah ditetapkan pada materi yaitu 66 .

Hasil belajar diperoleh dari skor postes siklus I dan siklus II.Berdasarkan skor yang diperoleh siswa diolah menjadi nilai hasil belajar. Untuk mendapatkan nilai hasil belajar dilakukan pengubahan skor menjadi nilai sebagai berikut:

$$
\text { Nilai siswa }=\frac{\text { Jumlah skor jawaban benar }}{\text { Skor maksimum }} \times 100
$$

Siswa dikatakan tuntas apabila nilai yang diperoleh lebih besar atau sama dengan kriteria ketuntasan minimal yaitu 66. Apabila nilai siswa di bawah 66 maka siswa dikatakan tidak tuntas. Untuk menentukan persentase ketuntasan kelas maka dilakukan perhitungan sebagai berikut:

$$
\% \text { Ketuntasan Kelas }=\frac{\text { Jumlah siswa yang tuntas }}{\text { jumlah siswa di kelas }} \times 100 \%
$$

Proses pembelajaran dikatakan berhasil apabila $80 \%$ pada siklus I dan 90\% pada siklus II siswa di kelas dapat mencapai KKM dari lembar observasi proses pelaksanaan proses pembelajaran yang terlaksana. Untuk menentukan persentase ketuntasan proses pembelajaran dilakukan dengan perhitungan:

$\%$ Proses Pembelajaran $=\frac{\text { Jumlah skor yang diperoleh }}{\text { Jumlah skor maksimal }} \times 100 \%$

\section{HASIL DAN PEMBAHASAN}

\section{Hasil Penelitian}

Untuk mengetahui proses pelaksanaan pembelajaran digunakan lembar observasi. Pengamatan kepada guru dilakukan observer dari awal hingga akhir proses pembelajaran. Pembelajaran dikatakan baik apabila $80 \%$ pada siklus I dan $90 \%$ pada siklus II indicator kinerja dari lembar observasi yang 
dilaksanakansesuai dengan rencana pelaksanaan pembelajaran yang dibuat. Hasil observasi proses pelaksanaan pembelajaran pada masing-masing siklus dapat dilihat padaTabel1.

\section{Tabel 1}

Proses Pelaksanaan Pembelajaran Melalui Penggunaan Media Animasidi Kelas XI IPA

SMA Negeri 2 Simpang Hilir Tahun Ajaran 2014/2015 pada Masing-Masing Siklus

\begin{tabular}{|c|c|c|c|c|c|c|}
\hline \multirow{3}{*}{ No } & \multirow{3}{*}{ Fase Pembelajaran } & \multirow{3}{*}{$\begin{array}{l}\text { No Item } \\
\text { Aspek } \\
\text { Penilaian }\end{array}$} & \multicolumn{2}{|c|}{ Siklus I } & \multicolumn{2}{|c|}{ Siklus II } \\
\hline & & & \multirow{2}{*}{$\begin{array}{c}\text { Persentase } \\
\%)\end{array}$} & \multirow[b]{2}{*}{ Kriteria } & Persentase & \multirow[b]{2}{*}{ Kriteria } \\
\hline & & & & & $(\%)$ & \\
\hline 1 & $\begin{array}{l}\text { Menyampaikan } \\
\text { Tujuan dan } \\
\text { Memotivasi Siswa }\end{array}$ & 1,2 dan 3 & & $\begin{array}{c}\text { Sangat } \\
\text { Kuat }\end{array}$ & 100 & $\begin{array}{c}\text { Sangat } \\
\text { Kuat }\end{array}$ \\
\hline 2 & $\begin{array}{l}\text { Menyajikan } \\
\text { Informasi }\end{array}$ & 4,5 dan 6 & & $\begin{array}{c}\text { Sangat } \\
\text { Kuat }\end{array}$ & 100 & $\begin{array}{c}\text { Sangat } \\
\text { Kuat }\end{array}$ \\
\hline 3 & $\begin{array}{l}\text { Mengorganisasikan } \\
\text { Siswa Kedalam } \\
\text { Kelompok Belajar }\end{array}$ & 7 & & $\begin{array}{c}\text { Sangat } \\
\text { Kuat }\end{array}$ & 100 & $\begin{array}{c}\text { Sangat } \\
\text { Kuat }\end{array}$ \\
\hline 4 & $\begin{array}{l}\text { Membimbing } \\
\text { Kelompok Bekerja } \\
\text { dan Belajar }\end{array}$ & $\begin{array}{c}8,9,10, \\
11 \text { dan } 12\end{array}$ & & $\begin{array}{c}\text { Sangat } \\
\text { Kuat }\end{array}$ & 100 & $\begin{array}{c}\text { Sangat } \\
\text { Kuat }\end{array}$ \\
\hline 5 & Evaluasi & 13 dan 14 & & $\begin{array}{c}\text { Sangat } \\
\text { Kuat }\end{array}$ & 100 & $\begin{array}{c}\text { Sangat } \\
\text { Kuat }\end{array}$ \\
\hline 6 & $\begin{array}{l}\text { Memberikan } \\
\text { Penghargaaan }\end{array}$ & 15 & & $\begin{array}{c}\text { Sangat } \\
\text { Kuat }\end{array}$ & 100 & $\begin{array}{c}\text { Sangat } \\
\text { Kuat }\end{array}$ \\
\hline & Rata-rata & & & $\begin{array}{c}\text { Sangat } \\
\text { Kuat }\end{array}$ & 100 & $\begin{array}{c}\text { Sangat } \\
\text { Kuat }\end{array}$ \\
\hline
\end{tabular}

Berdasarkan data tersebut tampak hasil pengamatan yang dilakukan oleh observer 1 dan 2 bahwa pada siklus I dan II masing-masing 100\% dengan kriteria sangat kuat. Artinya, observer melihat setiap fase dalam proses pelaksanaan pembelajaran dilaksanakan guru sesuai dengan rencana pelaksanaan pembelajaran.Hasil belajar siswa pada setiap siklus dapat dilihat pada Tabel 2 di bawah ini.

Tabel 2

Hasil Belajar Siswa Kelas XI IPA SMA Negeri 2 Simpang Hilir TahunAjaran 2014/2015 pada Masing-Masing Siklus

\begin{tabular}{|c|c|c|c|c|c|c|c|c|}
\hline \multirow[t]{3}{*}{ No } & \multirow{3}{*}{$\begin{array}{c}\text { No } \\
\text { Induk }\end{array}$} & \multirow{3}{*}{$\begin{array}{l}\text { Kode } \\
\text { Siswa }\end{array}$} & \multicolumn{6}{|c|}{ Hasil Belajar Siswa } \\
\hline & & & \multicolumn{3}{|c|}{ Siklus I } & \multicolumn{3}{|c|}{ Siklus II } \\
\hline & & & Skor & Nilai & Keterangan & Skor & Nilai & Keterangan \\
\hline
\end{tabular}




\begin{tabular}{|c|c|c|c|c|c|c|c|c|}
\hline 1 & 581 & $A G$ & 8 & 53,33 & Tidak Tuntas & 11 & 73,33 & Tuntas \\
\hline 2 & 559 & ED & 11 & 73,33 & Tuntas & 14 & 93,33 & Tuntas \\
\hline 3 & 529 & GU & 10 & 66,67 & Tuntas & 13 & 86,67 & Tuntas \\
\hline 4 & 496 & $\mathrm{HA}$ & 9 & 60 & Tidak Tuntas & 11 & 73,33 & Tuntas \\
\hline 5 & 509 & $\mathrm{RAH}$ & 10 & 66,67 & Tuntas & 13 & 86,67 & Tuntas \\
\hline 6 & 542 & RI & 8 & 53,33 & Tidak Tuntas & 10 & 66,67 & Tidak Tuntas \\
\hline 7 & 512 & SEL & 9 & 60 & Tidak Tuntas & 13 & 86,67 & Tuntas \\
\hline 8 & 514 & SYA & 10 & 66,67 & Tuntas & 13 & 86,67 & Tuntas \\
\hline 9 & 549 & ALD & 12 & 80 & Tuntas & 14 & 93,33 & Tuntas \\
\hline 10 & 586 & $\mathrm{DAH}$ & 7 & 46,67 & Tidak Tuntas & 9 & 60 & Tidak Tuntas \\
\hline 11 & 588 & DEF & 8 & 53,33 & Tidak Tuntas & 11 & 73,33 & Tuntas \\
\hline 12 & 590 & DES & 8 & 53,33 & Tidak Tuntas & 10 & 66,67 & Tidak Tuntas \\
\hline 13 & 591 & DET & 8 & 53,33 & Tidak Tuntas & 11 & 73,33 & Tuntas \\
\hline 14 & 600 & OK & 12 & 80 & Tuntas & 14 & 93,33 & Tuntas \\
\hline 15 & 510 & RAT & 12 & 80 & Tuntas & 13 & 86,67 & Tuntas \\
\hline 16 & 577 & $\mathrm{TI}$ & 12 & 80 & Tuntas & 13 & 86,67 & Tuntas \\
\hline 17 & 516 & TR & 10 & 66,67 & Tuntas & 11 & 73,33 & Tuntas \\
\hline 18 & 608 & WID & 13 & 86,67 & Tuntas & 13 & 86,67 & Tuntas \\
\hline 19 & 609 & WIN & 10 & 66,67 & Tuntas & 11 & 73,33 & Tuntas \\
\hline & Rata- & & & 65,61 & & & 80 & \\
\hline \multicolumn{5}{|c|}{$\Sigma$ Tuntas } & 12 & \multicolumn{2}{|c|}{$\Sigma$ Tuntas } & 16 \\
\hline \multicolumn{5}{|c|}{ Ketuntasan (\%) } & 63,15 & \multicolumn{2}{|c|}{$\begin{array}{c}\text { Ketuntasan } \\
(\%)\end{array}$} & 84,21 \\
\hline
\end{tabular}

Ket : Kriteria Ketuntasan Minimal (KKM) pada materi sistem koordinasi $\geq 66$

Berdasarkan tabelhasil belajar siswa menunjukkan bahwa siklus I terdapat 63,15\% siswa yang tuntas sedangkan pada siklus II angka ketuntasannya lebih tinggi yaitu84,21\%siswa yang tuntas. Siswa dikatakan tuntas apabila siswa memperoleh nilai $\geq 66$ (KKM 66). Adapun rata-rata nilai yang diperoleh siswa pada siklus I yaitu 65,61, sedangkan pada siklus II yaitu 80,00. Dari data tersebut tampak adanya peningkatan dari siklus I ke siklus II.

\section{Pembahasan}

Dalam model pembelajaran kooperatif terdapat 6 fase kooperatif yaitu penyampaian tujuan dan memotivasi siswa, menyajikan informasi, mengorganisasikan siswa ke dalam kelompok belajar, membimbing kelompok bekerja dan belajar, evaluasi dan memberikan penghargaan. 
Fase 1 adalah menyampaikan tujuan dan memotivasi siswa. Pada siklus I, fase ini disampaikan dengan baik, sesuai dengan pengamatan yang dilakukan oleh observer. Guru memberikan apersepsi dengan bertanya bagaimana organ yang satu dengan yang lainnya dapat membentuk suatu sistem?. Setelah itu guru menyampaikan tujuan pembelajaran dan menayangkan gambar struktur sel saraf (neuron), endokrin dan alat-alat indera pada manusia. Hal tersebut dilaksanakan agar siswa menjadi ingin tahu mengenai materi yang akan dipelajari, sehingga memotivasi siswa untuk belajar dengan bersungguhsungguh. Siswa-siswi antusias dan senang dengan sebuah pembelajaran yang menayangkan sebuah video animasi.

Pada fase 2 yaitu menyajikan informasi.informasi yang disajikan dalam fase ini yaitu menjelaskan sedikit materi awal kepada siswa dan kemudian guru menjelaskan bagaimana struktur sel saraf (neuron), endokrin dan alat-alat indera pada manusia. Siswa menyimak guru dengan baik.

Fase 3 yaitu mengorganisasikan siswa kedalam kelompok belajar.Setelah penyampaian materi tersebut, guru membagikan lembar kerja siswa (LKS) pada masing-masing kelompok sebagai pedoman pelaksanaan diskusi.LKS ini berisi pertanyaan-pertanyaan yang telah ditayangkan pada tahap penyajian materi melalui media animasi.Dengan demikian setiap siswa di dalam kelompok dapat berdiskusi secara efisien dalam menjawab pertanyaan.

Fase 4 yaitu membimbing kelompok bekerja dan belajar.Pada tahap ini guru membimbing siswa dalam berdiskusi dan mengarahkan siswa dalam menjawab pertanyaan-pertanyaan di dalam LKS.Pada siklus I siswa masih banyak bertanya khususnya bagaimana cara pengisian LKS (Lembar Kerja Siswa). Menurut Ibrahim, et al (2000), interaksi antar siswa dalam menyelesaikan tugas akan meningkatkan penguasaan mereka terhadap konsepkonsep yang sulit. Dengan demikian, semakin tinggi nilai yang diperoleh kelompok mengindikasikan bahwa semakin baik pula interaksi atau diskusi yang terjadi pada kelompok tersebut dalam pengerjaan LKS yang ditugaskan kepada mereka.

Fase 5 dan 6 yaitu evaluasi dan memberikan penghargaan.Pada tahap evaluasi, setiap kelompok diminta untuk melaporkan atau mempresentasikan hasil diskusi kelompoknya di depan kelas. Selanjutnya guru akan memberikan kesempatan kepada para siswa yang belum mengerti untuk bertanya.Penghargaan yang diberikan kepada kelompok-kelompok yang memperoleh nilai tertinggi mendapat bonus skor 5 poin.Pada pelaksanaannya fase 5 dan 6 tersampaikan dengan baik. Diakhir pembelajaran dilakukan tes hasil belajar guna melihat pencapaian pemahaman siswa terhadap materi tersebut, seperti yang telah dijelaskan oleh Mudjiono dan Dimyati (2009) 
bahwa "evaluasi hasil belajar bertujuan untuk mengetahui tingkat keberhasilan yang dicapai oleh siswa setelah mengikuti suatu kegiatan pembelajaran".

Di akhir pertemuan siklus I dan siklus II diberikan tes untuk mengetahui hasil belajar siswa.Soal tes mencakup semua materi yang dipelajari pada tiap siklus.Tes dikerjakan secara mandiri selama \pm 20 menit.Dengan adanya tes siswa diharapkan dapat menyadari bahwa pembelajaran yang dilakukan tidak hanya sekedar bermain-main tapi untuk meningkatkan hasil belajar mereka.Tes yang diberikan berupa pilihan ganda berjumlah 15 soal.

Hasil refleksi tindakan siklus I menunjukkan guru harus lebih memperhatikan kegiatan siswa dan alokasi waktu agar proses pembelajaran dapat berlangsung dengan baik dan waktu yang digunakan lebih efektif. Selain itu guru juga harus memperhatikan pengkombinasian model pembelajaran kooperatif dengan media animasi dapat terlaksana dengan baik. Kombinasi tersebut mengharapkan suatu pembelajaran menjadi student centered dan memberikan dampak yang baik terhadap hasil belajar siswa.

Media pembelajaran berupa video animasi diharapkan dapat membuat siswa merasa bersemangat untuk belajar dan tidak bosan. Kehadiran media tentunya sangat menunjang keaktifan siswa dalam proses pembelajaran. Seperti yang telah dijelaskan oleh Munadi (dalam anonim, 2008) bahwa untuk menjamin hasil belajar yang baik, maka siswa harus dihadapkan pada objekobjek yang dapat menarik perhatian, jika tidak maka perhatian siswa tidak akan terarah pada objek yang sedang dipelajarinya. Berdasarkan hasil refleksi, maka penerapan model pembelajaran kooperatif dengan media animasi dilaksanakan dengan perbaikan pelaksanaan pada siklus II.

Berdasarkan pengalaman pada siklus I dilakukan perbaikan pelaksanaan pembelajaran menggunakan model pembelajaran kooperatif dengan media animasi. Proses pelaksanaan pembelajaran tetap menggunakan Rencana Pelaksanaan Pembelajaran (RPP) yang telah didesain sebelumnya. Dikarenakan tahap-tahap dalam pembelajaran telah dilakukan oleh siswa pada pembelajaran sebelumnya, sehingga pada pembelajaran ini siswa dapat mengingat kembali hal-hal yang mereka lakukan sebelumnya. Perencanaan pembelajaran siklus II ini disiapkan Rencana Pelaksanaan Pembelajaran (RPP), Lembar Kerja Siswa/LKS dan media video animasi. Pada perencanaan tindakan ini membahas materi sistem koordinasi pada manusia.

Kegiatan yang dilakukan oleh siswa hampir sama dengan siklus I, dimana setiap kelompok menjawab LKS pada media dan LKS yang diberikan guru. Hasil belajar siswa diketahui menggunakan soal tes yang diberikan pada akhir siklus atau diakhir pertemuan. Selain itu terdapat observer mengamati 
proses pelaksanaan pembelajaran dan mengamati keaktifan siswa dalam penggunaan media animasi.

Berdasarkan perencanaan, siklus II dilaksanakan sebanyak 1 kali pertemuan.Adapun dalam pelaksanaan tindakan pada siklus II ini mengulas kembali sedikit tentang fungsi Saraf, tipe sel saraf, bagian sel saraf, serta susunan sistem saraf, dimana pada pelaksanaan ini menggunakan model pembelajaran kooperatif dengan media animasi.Pada tahap ini siswa sudah memahami bagaimana proses pembelajaran berlangsung, sehingga guru lebih mudah mengatur proses pembelajaran. Proses pembelajaran pada siklus II dengan tahap-tahap atau fase-fase yang sama dengan pembelajaran sebelumnya

Pada penyampaian apersepsi hampir seluruh siswa mengetahui apa yang akan mereka pelajari nanti dan siswa telah mempersiapkan diri dengan membaca buku teks yang mereka miliki. Kemudian guru menyajikan informasi berupa menjelaskan kembali materi sebelumnya. Dilanjutkan dengan siswa kembali kepada kelompok belajar yang telah ditentukan. Siswa belajar secara mandiri dan saling bekerja sama untuk memahami materi tersebut. Guru selalu memantau dan membimbing siswa agar siswa mudah memahami materi.

Siswa bekerjasama menjawab Lembar Kerja Siswa yang telah diberikan. Masing-masing kelompok selanjutnya mempresentasikan jawaban mereka didepan kelas untuk dikoreksi secara bersama-sama. Pada siklus II ini siswa lebih berani untuk memberikan tanggapan terhadap jawaban kelompok lain yang maju, sehingga keaktifan siswa dalam proses pembelajaran lebih baik sehingga dapat memotivasi teman-temannya yang lain.

Pada tahap akhir pembelajaran, siswa diberikan soal posttest untuk melihat ketuntasan belajar siswa atau melihat sejauh mana pemahaman siswa terhadap materi tersebut dan sebagai pembanding pada siklus I sebelumnya, sebagaimana yang telah dijelaskan oleh Michael (dalam Suryosubroto, 2009) mengenai tujuan evaluasi formatif salah satunya adalah untuk menemukan sampai seberapa jauh siswa telah menguasai bahan pelajaran.

Dari hasil tes siklus I, 12 orang siswa atau $63,15 \%$ dinyatakan tuntas dengan nilai rata-rata 65,61 dan 7 orang siswa atau 36,85\% dinyatakan tidak tuntas. Sedangkan pada tes siklus II ketuntasan belajar siswa naik menjadi $84,21 \%$ dengan nilai rata-rata 80 . Sedangkan proses pelaksanaan pembelajaran pada siklus I dan siklus II yaitu 100\%. Dari hasil tes siklus I dan siklus II, diketahui bahwa proses belajar mengajar dengan menggunakan media animasi dapat meningkatkan hasil belajar siswa. Peningkatan hasil belajar siswa dapat terjadi karena pembelajaran menggunakan media animasi dapat menjelaskan segala proses yang terjadi pada sistem koordinasi manusia secara detil. Sehingga siswa dapat lebih memahami proses pada sistem koordinasi manusia. 
Adapun menurut Ariyani dan Haryanto (2010) teknologi multimedia mampu memberikan dampak besar dalam komunikasi pendidikan karena bias mengintegrasikan teks, grafik, animasi, audio, dan video serta mengembangkan proses belajar kea rah yang lebih dinamis.

\section{KESIMPULAN}

Berdasarkan hasil analisis data dapat disimpulkan bahwa proses pembelajaran yang dilakukan oleh guru pada siklus I dan siklusII terlaksana dengan baik (100\%) kriteria sangat kuat. Penggunaan media animasi dapat mendukung proses pembelajaran yang baik serta dapat meningkatkan hasil belajar siswa.Adapun tes hasil belajar siswa pada siklus I rata-rata nilai yaitu 65,61dengan ketuntasan $63,15 \%$. Pada siklus II yaitu rata-rata nilai 80,00 dengan ketuntasan $84,21 \%$. Dengan demikian penggunaan media animasi dapat dijadikan sebagai alternatif dalam strategi pembelajaran khususnya pada materi Biologi.

\section{DAFTAR RUJUKAN}

Adri, M. 2008. Flash - Case on Teks Animation. http:ilmucomputer.com. Diakses pada tanggal 25 Agustus 2015.

Arikunto. 2010. Prosedur Penelitian suatu Pendekatan Praktik. Jakarta: Rineka. Cipta.

Ariyani, Niken dan Haryanto, Dani. 2010. Pembelajaran Multimedia di Sekolah.Surabaya: Prestasi Pustaka

Ibrahim, M, et al. 2000.Pembelajaran Kooperatif. Surabaya: UNESAUNIVERSITY PRESS.

Kusumah, Wijaya dan Dwitagama, Dedi. 2011. Mengenal Penelitian Tindakan Kelas. Jakarta: PT. Indeks.

Rusman. 2010. Model-Model Pembelajaran: Mengembangkan Profesionalisme Guru. Jakarta: PT. Raja Grafindo Persada.

Sanjaya, W. 2008. Strategi Pembelajaran BerorientasiStandar Proses Pendidikan. Jakarta: Kencana Prenada Media Group.

Utami, D. 2007. Animasi dalam Pembelajaran. www.uny.ac.id/akademik/ default.php. Diakses pada tanggal 25 Agustus 2015. 